\title{
Poetic Inquiry: A Fierce, Tender, and Mischievous \\ Relationship with Lived Experience
}

\author{
SEAN WIEBE \\ University of Prince Edward Island
}

\begin{abstract}
Common to poetic inquirers is a sensitivity to the ways traditional qualitative analysis can systematize and simplify, oftentimes generating theories and practices that are out of kilter with our intuitive experience of being in the world. In this paper I look at how the richness of lived experience can be sustained in poetic inquiry, and in so doing, offer the terms fierce, tender, and mischievous as qualities of engagement that are often exemplified in the ways poetic inquirers live and work.
\end{abstract}

\section{Introduction}

In the first half of this paper, I refer primarily to Rapport and Hartill's (2012) article published in Creative Approaches to Research, a special issue of poetic inquiry in the social sciences, edited by Kate Galvin and Monica Prendergast. Because Rapport and Hartill found poetic inquiry to be a powerful tool in their ethnographic research, I am curious about what it is within poetic inquiry that they find so powerful. My general line of reasoning is inductive, asking what it is about Rapport and Hartill's specific experience with poetic inquiry that might provoke discussion more generally.

Rapport and Hartill are not the only ones to find poetic inquiry a powerful way of engaging the world. Prendergast and Galvin (2012), looking back over the field, advance poetic inquiry as "in depth qualitative research" (p. 5); five years earlier Prendergast (2007) completed a 1082 page annotated bibliography detailing the use of poetry in the social sciences, a work that took the entirety of her postdoctoral fellowship with Carl Leggo. While studying with Leggo, Prendergast hosted the inaugural poetic inquiry conference at the University of British Columbia (2007), and since then there have been seven important collections of poetic inquiry that have expanded the field: three edited book collections, Poetic Inquiry: Vibrant Voices in the Social Sciences (Prendergast, Leggo \& Sameshima, 2009); The Art of Poetic Inquiry (Thomas, Cole \& Stewart, 2012); and Poetic Inquiry II: Seeing, Understanding, Caring (Galvin \& Prendergast, forthcoming); and four special issue journals: Educational Insights, 13(3) (Prendergast, Leggo, \& Sameshima, 2009); Learning Landscapes, 4(1) (Butler-Kisber, 2011); Creative Approaches to Research, 5(2) (Galvin \& Prendergast, 2012); and in education, 20(2) (Guiney Yallop, Wiebe, \& Faulkner, 2014).

In the second half of this paper, my inductive reasoning becomes more teleological ${ }^{1}$, where I try out a psychoanalytic and synoptic idea, considering how the

\footnotetext{
${ }^{1}$ Biesta (2010) argues that all reasoning is at least partly teleological reasoning. Thinking is a human activity oriented by a telos - an aim or purpose — and cannot be an a priori cognitive process. Because the human mind is not a processing machine, methodological questions about the effectiveness or
} 
terms fierce, tender, and mischievous - if taken contiguously_might have potential for enriching those discussions of poetic inquiry that are more methodological. Because poetic inquiry is not directly about what researchers do with a text, but speaks also to the ways we find meaning in living and being, we need to make room in our scholarly conversation to contemplate the teleological aspects of inquiry. What can be learned from the poet's fierce/mischievous openness to the aesthetic qualities of human experience? Or, how might a poet's tenderness enhance the pursuit of knowing human experience more deeply? The teleological in the contiguous terms fierce, tender, and mischievous focus us on the purposes and values that hold up our methods. Meyer (2010) says, "we are never world-less" (p. 85). Applied to poetic inquiry, I understand Meyer to be saying that our work is bound - in some way - to the world, its worldliness. Being in and part of the world, whether we are contemplating it, interpreting it, re/visioning it, or something else entirely, to inquire poetically is to attune our senses to this world. Inquiry, after all, must be to remain open to the possible, multiple contiguous relationships for the poet/inquirer to find the right distance between the self and other, between the researcher and the participant, and between the poet and the poetry. Though we might wish it otherwise, our embodied and social existence in this world is not straightforward or transparent - and so I wonder how a fierce, tender, and mischievous engagement with the worldliness of our lives might allow us to reshape it and make something new-we might call this learning — we might call it poetry.

\section{Sensory Attunement}

Attuned through their senses, poetic inquirers open themselves to what matters in lived experience: some of these have included visual re/creation (James, 2009; Richardson, 2013), heartful contemplation (Faulker, 2012; MacKenzie, 2013), and performative speculation (Dark, 2009; Fels, 2012). While any of the above would have served the aims of a detailed analysis, I've selected Rapport and Hartill's (2012) Crossing Disciplines with Ethnographic Poetic Representation as an exemplar because of their practice of sustained sensory attunement: they exemplify constancy in being attuned to the worldliness of being, even in the midst of the unexpected action of their lives.

For example, Rapport (2012) describes just such an unexpected moment of hearing: In the middle of dinner with her mother, another diner overheard their conversation and was angry with them for conversing about the Holocaust, "What do you know about the Holocaust? [he said] ... You have no right to talk like that in public" (p. 12). At first received as an attack, then reconsidered as a challenge, and again reconsidered as an opportunity to care, Rapport asked herself whether it would be possible to approach her Holocaust research with the usual ethnographic processes. Perhaps the man crashing in on her conversation was right-what did she know? After all, her research knowledge would always be indirect and distant, perhaps even overly academic, especially given the representational constraints that so often narrow the expressive possibilities for many social sciences researchers (Denzin \& Lincoln, 2011).

trustworthiness of a set of procedures - as those we might image take place in poetic inquiry - are importantly, and always, secondary to questions of purpose. Biesta writes: "It is only when we have provided an answer to what we hope achieve that we can begin to ask questions about the ways in which we might be able to achieve such outcomes" (p. 500). 
As a way of responding to this representational crisis, ${ }^{2}$ it is not surprising (for those of us who regularly locate our work in poetic inquiry) that Rapport turns to poetic transcription, what Prendergast (2004) has called an ekphrastic process, because of the way transcription constructs a dialogical response to the original work, experience, or phenomenon. Examining "the roots, histories and practices of different literary and research applications," from their different disciplinary perspectives, Rapport and Hartill (2012) emphasize that their turn to poetic inquiry added "literary theory and form" to their already substantial repertoire of ethnographic methods (p. 17). For them, this meant they could use poetic inquiry as a "powerful and creative tool" (p. 12), one they felt was ideally suited for researching difficult narratives.

Rapport and Hartill's description of the selection process for determining the most suitable analytical methods is useful in making explicit why so many turn to poetic kinds of analysis. They reject the usual complement of analytic processes, as "thematic analysis (Ezzy, 2002), content analysis (Neuendorf, 2002), or framework analysis (Robson, 2002) seemed strangely inappropriate" (p. 19). Why? The usual forms of analysis, they argue, reduce "the ebb and flow of words to clipped lists of thematised events, behaviours, actions and interactions" (p. 19). Rapport and Hartill (2012) also note that "applying a computer-analysis programme to the material... to count the frequency of words and reveal 'nested categories' alter[s] the sense of the conversations and detract[s] from the storyteller's voice" (p. 19). In the practice of poetic inquiry, researchers become sensitive to the ways traditional analysis can systematize and simplify, generating findings that are "out of kilter with the flowing resonance of the raw material" (Rapport and Hartill, 2012, p. 19); this is why so many poetic inquirers emphasize the richness of the story and the storyteller's voice as first priority values.

Paying attention to her own writing/research processes in that borderland space between scholarship and art, Rapport describes how she spent "extensive time listening to their stories" because they wanted their ekphrastic text to be mediated by "the authenticity of the spoken word" (p. 13). Rapport underscores her "painstaking process of reading and re-reading transcripts, understanding, distilling, explicating and eventually re-presenting their content according to research scenarios inherent within them" (p. 13). In addition to the extensive, even painstaking process of textual analysis, Rapport points to what guided her analytical decision-making: "the scenarios inherent within [participant stories]" (p. 13), later described as "letting the stories speak for themselves, sensitively working with the detail to allow texts to reveal their own transformations" (p. 19).

While this kind of a process might sound a bit mysterious - reading and rereading until the text reveals its key messages - it is a central part of the commitment to artistic

\footnotetext{
${ }^{2}$ Following Denzin and Lincoln (2011), Prendergast and Galvin (2012) note that part of the dilemma facing researchers in the 'crisis' of representation is that "the voices of participants were too often appropriated, overpowered, fragmented, rendered over-summative or even silenced" (p. 5). In foregrounding researcher's ethical responsibilities, however, Denzin and Lincoln have lost sight of the more significant point that there is no reliable or valid means of representing reality. What Marcus and Fischer (1999) called a crisis was the fact that there are no adequate means to describe reality. It is probably a misnomer to call it a crisis today as it no longer considered controversial to claim that A is not A. Aoki's (2002) fabulous essay, "The Thing Never Speaks for Itself" explains in Lacanian terms why there is a gap between signifier and signified (i.e., why A is not A). And for a more historical account of this shift from structuralism to post structuralism, I can refer you to my own paper on the subject, "Aesthetic/Empathetic Punctures through Poetry: A Lacanian Slip into Something Other than Education (Wiebe, 2013).
} 
processes that many poetic inquirers share. Susan Walsh (2012) describes her process as being present and dwelling with particular artifacts rather than analyzing or interpreting them (p. 273). She says this involves listening to the text, asking what it wants her to do (p. 274). Eisner (2005) writes that "as we learn to think within the medium we choose to use, we also become more able to raise questions that the media themselves suggest" ( $\mathrm{p}$. 181). It seems to me that each medium, each form, has within it a slightly different kind of thinking, and that this thinking - which provides direction for how to proceed with representing the knowledge-does not become apparent without sustained contemplation.

Thinking of Rapport and Hartill's work (2012) as an exemplar of poetic inquiry, I wonder what can be learned from their openness to the aesthetic within their participants' stories, and how this might enhance the pursuit of knowing human experience more deeply. Eisner (2005) provides encouragement for this kind of curiosity: he says that "our capacity to wonder is stimulated by the possibilities that new forms of representation suggest" (p. 181). Because Rapport and Hartill (2012) found poetic inquiry to be a powerful tool in their ethnographic research, I am curious about what it is within poetic inquiry that creates an authentic connection between researchers and texts/experience, enough so that Rapport feels confident claiming her representational poetry conveys what the Holocaust was really like.

\section{Poetic Inquiry as a Way of Being}

I would argue that poetic inquiry operates as more than a tool in the above kinds of difficult research queries; it seems to me that Rapport and Hartill's (2012) enthusiasm for poetic inquiry comes not so much in the possibility that it is a tool, but more in the notion that it is a practice, inspiring a way of being in the world. This distinction is exemplified nicely in the difference between writing poetry and living poetically; now a grandfather of poetic inquiry (Leggo, in press), Leggo (2005) recalls a conversation with a graduate student, where, in response to a question of whether he was still writing poetry, the student replied that he was living poetically. So taken with this response, Leggo (2004) has described the idea of living poetically as central to his work and way of being in the world. Like so many others who have flourished under Leggo's mentorship, I can attest to the prophetic and pedagogical ways that Leggo lives out his poetic calling (Wiebe, 2014; Wiebe, 2015).

Additionally, still curious about the notion of tools (poetic inquiry), those who use them (poets), and the kinds of connections there are between them (living poetically), I am reminded of Heidegger's (1977/1993) idea that tools are extensions of the user. He explains that the tools we encounter in our experience take their meaning in how we understand them. For example, the same rock that we use to drive in the tent stake might also be the one that we put in our pocket because its texture catches our aesthetic imagination. That is, tools are not solely objects with their own independent properties but depend just as much on how we understand them in our ways of being in the world. In The Tacit Dimension, Polanyi (1966) extends this idea, suggesting that the rock-if we encounter it daily in a particular way-is no longer part of our conscious observation. What follows is his definition of tacit knowledge, that knowledge operating in the background of our attention can become part of us in the same way that our heart beats, unconsciously. Should the rock become a specific tool with a routine technique - for example, how it can become a hammer with an optimal range of motion for swinging, 
then tacit knowledge suggests that the hammer is not just ready-at-hand (Heidegger, 1977/1993), but an extension of the hand, enough so that we can notice how a man with a hammer will likely frame a solution to his problem in reference to the hammer he holds, and, ironically, just as often in reference to the hammer he no longer even knows he is holding. While many use these arguments to explain why it is possible to hold beliefs without knowing why or even how they were acquired, in Heidegger and Polany we also have an explanation for how our practices, rituals, and ways of being can matter more than any acquired tool or learned technique.

Returning to Rapport and Hartill (2012) who notice how too often traditional qualitative methods are "out of kilter with the flowing resonance of the raw material" ( $p$. 19), I am lead to ask: What kinds of researchers are drawn to poetic inquiry? What do they value? How do they construct their life world and position themselves within it? What does it mean to live well within that construct? These teleologically oriented questions emerge from the in between space of the tool and the tool user, between the space of the poet and poem, the researcher and the methodology.

\section{The Tool and Tool User; The Poem and the Poet}

In the early winter of 2008, sitting somewhat nervously on the loveseat with my partner, our therapist shared his orienting synopsis of what every relationship needed, which was also the same framework he used to guide his own work in couples counselling. What it opened up for me was profound, and as soon as I'd heard it I knew this was something I'd be returning to in my own thinking and writing (Wiebe \& Snowber, 2009). While I no longer have the memory to quote him directly, the gist of what he said is that in a working relationship each partner needs to be fierce, tender, and mischievous with one another. Different contexts and occasions call for a different blend of these attributes, and because relationship success involves learning a variety of blends, important is creating the space for each of these attributes to play out.

I remember that it was not easy for me to accept the necessity of my partner sometimes being more fierce than tender, and equally difficult was imagining what it would be like to discover what being mischievous might look like. Today I'm wondering if there isn't something in the possible combinations of these attributes that can provide an orienting explanation for poetic inquiry. Might it be that researchers drawn to poetic inquiry have always/already been poets, perhaps in the way they have felt fierceness, tenderness, and mischievousness within themselves?

As I contemplate the reasons for Rapport and Hartill's (2012) enthusiasm for poetic inquiry, it seems to me that the various blends implied in the contiguous terms fierce, tender, and mischievous are helpful in thinking about what I see as Rapport and Hartill's five contributions to addressing the question, "What is poetic inquiry?" These are: (1) in a blend of fierce/tender, attending to the humanness of the participants and holding firm the intention to consider how their words are not just findings but "disclosure[s] of the individual" (p. 18); (2) — in a blend of fierce/mischievous, waiting for, even expecting the unexpected, which means being "prepared for the unexpected to happen" (p. 18); (3) - in a blend of mischievous/tender, avoiding premature arrival at one truth and instead "journeying towards possible, multiple truths" (p. 18); (4) - in a blend of tender/mischievous/fierce, opening themselves to their artistic processes and developing these through study of "literary theory and literary forms" (p. 18); and (5)-in a 
re/mixing of all the blends, committing to an iterative process (p. 19), where, in what Richardson (2000) has called "creative analytical practices" the artistic forms created as part of the analysis become artifacts for further analysis.

In light of my argument that poetic inquiry involves the qualities of being fierce, tender, and mischievous, consider again this instigating moment for Rapport's ethnographic work: "What do you know about the Holocaust?" (p. 12). What I hear is How dare you, but also I dare you. It is the taunting voice of the difficult, the impossible; and I suspect that it is this unsilenceable voice that summons Rapport and Hartill's research questions. Rapport (2012) writes:

I recognised the enormity of a proposal that was forming in my mind; to take forward this taunt and through my own research ...give these words the continuity and permanency they deserved... in order to reach the end of a fleeting, interrupted and upended story (p. 13).

With tenderness for a story that had been upended, interrupted, and fleeting, Rapport replies with fierceness to the taunt that such a story cannot be told. Her compassionate hearing is also daring. Rather than shy away from the impossible she sees a challenge. Is this not at the heart of poetic inquiry - to listen for difficult knowledge but then not be afraid to address it? To be clear, this is not the problem/solution binary. Rapport, mischievously, moves ahead without any guarantee or answers. She knows to expect the unexpected and that there will be multiple truths along the way. Her research exemplifies the intricate balance of a fierce pursuit of answers, a tender care for the participants as humans, and a mischievous curiosity that refuses easy answers:

How does one attempt to study personal testimonial gathered from an extraordinary event such as the Holocaust? Is it possible to examine the event's impact on an individual's perception of the trauma they suffered and their health and wellbeing needs? Can ethnographic poetic representation, delivered from research conversations with a survivor, be presented back to that survivor in a way that is meaningful to them, and acceptable and accessible to wider audiences? (p. 12).

There is a quest implied in these research questions, and as much as a quest implies journey, it also suggests an undertaking of significant effort; few things in our lives can be described as quests for quests are understood as long-term commitments with transformative possibilities. Notice, too, how these research questions combine the tenacity of curiosity with the tenderness of compassion. Rapport is concerned for her participants' "health and wellbeing," (Rapport, 2012, p. 12), acknowledging the trauma they suffered, and ensuring that the findings they generate are meaningful to them. Balanced by tenderness, a poetic inquiry that is fierce does not fall into being ferocious or intimidating.

There is something about the tenacious/tender contiguity that is paradoxical, even impossible. When Rapport and Hartill (2012) wonder whether it is possible to both examine and care, to do what is necessary but to also do no harm, they give attention to a history of doing research that has privileged a hardness, a toughness, a rigour. In my etymological curiosity, I find it interesting how this preference for being tough in research is reflected in the history of the English language: From the Oxford online 
dictionary, I learn that the Old English, toh, to be tough, was directly contrasted with the Old French, tendre, to be soft, delicate, or young. The contrasting usages referred first to meat, the toh being the hard, chewy parts, and the tendre being the soft, undeveloped parts. Presumably, because younger animals had softer meat, the contrast between toh and tendre easily encompassed the idea of men being strong and powerful, and boys being tender and mild. And by the thirteenth century this is confirmed in the common usage, as toh was most often used developmentally to mean not tender, not a boy, not delicate. By the twentieth century the notion of tough included not just the body, but the mind. One could exercise the mind like the body with the objective of developing a tough mind.

What has been lost-perhaps because the historical male fear of being weak has exaggerated the difference between English and French, men and boys, or tough and tender - is the in between sense of being stretchy, stringy, or resilient. Interestingly, in the twelfth century tendre also referred to the cartilage. Tendre comes from the Latin, ten, meaning stretchy or stretched. Something stretched was thin, or weakened, but it was also flexible. Also from the Latin, ten, is tenere, meaning to hold, and it commonly referred to string, which, because it was stretchy (tendere) could be used to hold things fast together (tenere). Going back to the metaphor of the body, in the young body the tendons are flexible and tough, connecting muscle to bone. As the body ages, the tendons get stiffer (too tough) and less stretchy (shorter) and this hampers the overall muscle capability.

What is interesting to me in this etymology of tenacious/tender is that the history and properties of the one are also significantly observable in the other. This contiguity, when stretched to include a third term-mischievous, is my attempt at a working conception of what it means to poets practicing poetic inquiry. The beauty of a threeterm conception is that the possible, multiple contiguous relationships create intellectual/personal room for the poet/inquirer to find what Taubman (1992) calls the right distance between the self and other, between the researcher and the participant, and between the poet and the poetry. What the notion of the right distance challenges us to understand is that each moment of our lives calls for a different degree of emphasis and a different variation of what we know to be true. Thus, with the three terms, allowing for multiple arrangements that would have varying degrees of emphasis-such as fierce/tender/mischievous or tender/mischievous/fierce - the possible intertwining relationships quickly reaches beyond human capacity to structure and systemize them, especially when each term is understood post structurally, where there is an ongoing and infinite difference between the signifier and signified. In pursuing the question, "What is poetic inquiry?" we can expect that it will be a quest that lasts a lifetime.

\section{So, What is Poetic Inquiry?}

As a poetic inquirer I am trying to say something definitive about the methodology, and in grappling with the raw material of Rapport and Hartill's (2012) work, I've found not so much a method, but a way of being. I think Rapport and Hartill offer us five ways of being in poetic inquiry: these are (1) attending to and prioritizing humanness, (2) expecting the unexpected, (3) holding forth for multiple truths; (4) exploring literary form and theory, and (5) creating possibility through iterative remixing. However, because poetic inquiry is not directly about what researchers do with a text, but speaks also to the ways we find meaning in living and being, perhaps there is room-as I have suggested 
above, to contemplate the teleological aspect of inquiry. Teleological practices, those framed by telos, are simply those that have an aim or purpose. Supposing fierce, tender, and mischievous to be immanent to poetic inquiry, then our methods and arguments for them would be made with a view to what we considered valuable in our relationships with one another and the world we cannot help be part of. The teleological in the contiguous terms fierce, tender, and mischievous focus us on the purposes and values that hold up our methods. The issue, after all, must be to remain open to the possible, multiple contiguous relationships for the poet/inquirer to find the right distance between the self and other, between the researcher and the participant, and between the poet and the poetry.

In testing whether a teleological approach might be incommensurate with inductive reasoning, I've tried out the terms fierce, tender and mischievous to see if they ring true in the experience of someone using poetic inquiry for the first time.

Jennifer Finn, an education scholar and multi-talented artist, recently challenged herself to try poetic inquiry (Finn, 2015). Like many new to poetry, she was reluctant to name herself as a poet, but seriously valuing her creative self, she describes her attraction to poetry this way: "I crave the raw experience of being alive and I find it when I get outside of my comfort zone" (p. 3). Initially setting out to write one poem per day on her blog, she found unpredictability instead, as poetry took her "into raw and vulnerable places without warning" (p. 4). The contrast between the first poem of her plan, which she says was "very easy to share" (p. 7), and her later poetry, is worth close attention. Here is the first poem she wrote:

The body of the earth radiating soul out from beneath... the rhythm of your beating heart the apple oatmeal crisp the deep blue ocean eyes of our children

Innocence and enchantment align in these things.

From this magic,

wonder is reclaimed.

Wholeness is born. (Finn, 2015, p. 7).

Writing a poem everyday did not work for her. When focussed on the plan, or the method, or the message, she noticed that she was too abstract: "There were times that I wanted to delete, hide, or mask what was true in the moment," (p. 7) so would "jump to abstractions, rather than attend to the details of the moment" (p. 5). She noticed that what poetry was offering was an opportunity to be more honest and intimate with herself and her experience with the world. In order to find "a rich pedagogical landscape" (p. 7) she felt she needed to create more space and time for feeling her vulnerabilities more deeply. The contrasting poem, in a section of her paper titled, "When it Rings True" illustrates why poetic inquirers resist offering reductive methodologies: 
My Dad pooped in a bag for years

and years and years

almost his whole life,

as long as I knew him.

We never talked about it.

Not until he died.

The silence that covers the shit and the shame

was almost too much to bear.

I took the bag off of his paralyzed, lung-cancered body.

His deep blue Irish eyes met mine,

locked in trust,

and through my squinched up nose

I summoned every ounce of Love I had for that man,

and shot it through the eyes that I got from him.

He trusted me with his shit,

and freed me from the dark thoughts that plagued him. (Finn, 2015, p. 11)

Finn (2015) knows that when what comes out aligns with what is happening within, then that is when the magic happens. But, "sometimes that magic hurts" (p. 11). Even with all her experience in the arts, Finn notes how she was still surprised by how her "father's deepest wound wove its way onto my paper" (p. 11). For Finn, being open to the unexpected, but also the hurt that can come with the unexpected, is what makes her feel alive, honest, and empowered: "When I am aligned with the truth of the moment, I can feel my heartbeat" (p. 3). Given her positioning as someone new to the field, what are we to make of Finn's experience with poetic inquiry? Is it fair to say that her poetry became more powerful once she allowed herself to be vulnerable and open, unattached to the formalities of what is expected? Are the contiguous possibilities of the terms fierce, tender, and mischievous useful for describing her way of being a poet? Here is what Finn (2015) says:

We are not separate from life, but integral to it. Poetry honors this relationship, and reaches out to and from the human heart, embodying through artistic form what it means to be alive. Because of this intimacy with life, poetry is a very powerful mode of inquiry that invites us into the vitality of life, and then pulls us out in brave ways. (p. 5)

I would not be the only one to suggest that poetic inquiry continues to thrive through such ongoing provocations of vitality in life. As Prendergast and Galvin (2012) recently note: poetic inquirers "help readers resonate and connect with findings; new ways of revealing deep understandings of human experience; ... and new ways of working with people in vulnerable situations to name "what it is like" (p. 5). This focus on the new is not so much for the sake of being innovative, but more so in recognition of the infinite iteration of difference, both from what is proposed as the original (however temporary), and from itself in its own resemblance to what the original once was. Along 
these lines, in the introduction to their forthcoming collection on poetic inquiry, Galvin and Prendergast describe their text as "a novel collection of international works on the methodological use of poetry that transcends conventional disciplinary boundaries" (p. i). It is our fierce insistence to challenge traditional research that brings the necessity of art into the public sphere. And it is our tenderness with one another that nurtures our differences, creating understanding and value for the affective and aesthetic components of who we are in relation to the work that we do. And it is our mischievousness that allows us - as Rapport and Hartill (2012) have - to see any dare that it cannot be done as an opportunity to be poetic in our pursuit of knowing human experience more deeply.

\section{References}

Aoki, D. S. (2000). The thing never speaks for itself: Lacan and the politics of clarity. Harvard Educational Review, 70, 347-369.

Biesta, G. (2010). Why "what works" still won't work: From evidenced-based education to value-based education. Studies in the Philosophy of Education, 29, 491- 503.

Butler-Kisber, L. (2011). The art of poetic inquiry. In S. Thomas, A. L, Cole, \& S. Stewart (Eds.), The art of poetic inquiry. Halifax, NS: Backalong Books.

Dark, K. (2009). Examining praise from the audience: What does it mean to be a successful poet researcher. In Prendergast, M., Leggo, C., \& Sameshima, P. (Eds). Poetic inquiry in the social sciences: Vibrant Voices (pp. 171-185). Amsterdam: Sense Publishing.

Denzin, N. K., \& Lincoln, Y. S. (2011). Introduction: The discipline and practice of qualitative research. In N.K. Denzin \& Y.S. Lincoln (Eds.), The SAGE handbook of qualitative research (pp. 1-20). Thousand Oaks, CA: Sage.

Eisner, E. (2005). Reimagining schools: The selected works of Elliot W. Eisner. New York, NY: Routledge.

Ezzy, D. (2002). Qualitative Analysis: Practice and Innovation. Sydney: Allen and Unwin.

Faulkner, S. L. (2012). Frogging It: A poetic analysis of relationship dissolution. Qualitative Research in Education, 1(2), 202-227. DOI:10.4471.qre.2012.08

Fels, L. (2012). Collecting data through performative inquiry: A tug on the sleeve. Youth Theatre Journal, 26(1). 50-60.

Finn, J. (2015). An artist's experience of exploring her creative edge. Journal of Sustainability Education, 9, 1-15. Retrieved from: http://www.jsedimensions.org/wordpress/wp-content/uploads/2015/03/Finn-JSEMarch-2015-Love-Issue.pdf

Galvin, K. T., \& Prendergast, M. (in press). Poetic inquiry II: Seeing, understanding, caring: Using poetry as and for inquiry. Rotterdam, NL: Sense Publishers.

Guiney Yallop, J., Wiebe, S., \& Faulkner, S. (2014). The practices of poetic inquiry. in education, 20(2), 1-11.

Heidegger, M. (1977/1993). The question concerning technology. In D.F. Krell (Ed.), Martin Heidegger: Basic writings (W. Lovitt, Trans) (pp. 307-342). New York: Harper Collins. 
James, K. (2009). Cut-up consciousness: Poetic inquiry and the spambot's text. In M. Prendergast, C. Leggo \& P. Sameshima (Eds.), Poetic inquiry: Vibrant voices in the social sciences (pp. 59-74). Rotterdam: Sense Publishers.

Leggo, C. (2004). Living poetry: Five ruminations. Language \& Literacy: A Canadian Educational E-Journal, 6(2). Retrieved from: http://ejournals.library.ualberta.ca/index.php/langandlit/article/view/16309/13087

Leggo, C. (2005). Pedagogy of the heart: Ruminations on living poetically. Journal of Educational Thought, 39(2), 175-195.

Leggo, C. (in press). The unpredictability of bliss: A grandfather's poetic riffs. In K.T. Galvin \& M. Prendergast (Eds.), Poetic inquiry II: Seeing, understanding, caring: Using poetry as and for inquiry. Rotterdam, NL: Sense Publishers.

Marcus, G. E., \& Fischer, M. J. (1999). Anthropology as cultural critique: An experimental moment in the human sciences. Chicago: University of Chicago Press.

MacKenzie, S. K. (2013). Poetic praxis: Engaging body, mind, and soul in the social foundations classroom. Journal for Learning through the Arts: A Research Journal on Arts Integration in Schools and Communities, 9(1). Retrieved from: http://www.escholarship.org/uc/item/15g9b91z

Meyer, K. (2010). Living inquiry: Me, my self, and other. Journal of Curriculum Theorizing, 26(1), 85-96.

Neuendorf, K. A. (2002). The content analysis guidebook. Thousand Oaks, CA: Sage Publications.

Polanyi, M. (1966). The tacit dimension. Garden City, NY: Doubleday and Co.

Prendergast, M. (2004). Ekphrasis and inquiry: Artful writing on arts-based topics in educational research. Proceedings of the Imaginative Education Research Group conference. Retrieved from: www.ierg.net/confs/2004/Proceedings/Prendergast_Monica.pdf

Prendergast, M. (2007). Poetic Inquiry: An annotated bibliography (Unpublished postdoctoral dissertation). Centre for Cross Faculty Inquiry, University of British Columbia, Vancouver, British Columbia.

Prendergast, M. (2009). Poetic inquiry is ... 29 ways of looking at poetry as qualitative research. Educational Insights, 13(3). Retrieved from: http://www.ccfi.educ.ubc.ca/publication/insights/v13n03/intro/prendergast.html

Prendergast, M., Leggo, C., \& Sameshima, P. (2009). Poetic inquiry: Vibrant voices in the social sciences. Rotterdam: Sense Publishers.

Prendergast, M., \& Galvin, K. T. (2012). Editorial: Naming and expanding the borders of practice in poetic inquiry. Creative Approaches to Research, 5(2), 5-8.

Rapport, F., \& Hartill, G. (2012). Crossing disciplines with ethnographic poetic representation. Creative Approaches to Research, 5(2), 11-25.

Richardson, L. (2000). Writing: a method of inquiry. In N. K. Denzin \& Y. S. Lincoln (Eds.), The handbook of qualitative research. 2nd ed. (pp. 923-49). Thousand Oaks, CA: Sage.

Richardson, P. (2013). The mermaid \& the minotaur: The iermagined inner-life of women intellectuals in love. Paper presented at the 6th Biennial Provoking Curriculum Studies Conference, University of Ottawa. Ottawa, ON.

Robson, C. (2002). Real world research (Vol. 2). Oxford: Blackwell publishers. 
Tender [Def. 2.3]. (n.d). In Oxford Online Dictionary. Retrieved June $4^{\text {th }}$, 2015, from http://www.oxforddictionaries.com/us/definition/english/tender.

Taubman, P. (1992). Achieving the right distance. In W. Pinar and W. Reynolds (Eds.) Understanding curriculum as phenomenological and deconstructed text (pp. 216233). New York: Teachers College Press.

Thomas, S., Cole, A., \& Stewart, S. (2013). The art of poetic inquiry. Big Tancook Island, NS: Backalong Books.

Walsh, S. (2012). Contemplation, artful writing: Research with internationally educated female teachers. Qualitative Inquiry, 18, 273-285. DOI: $10.1177 / 1077800411431553$

Wiebe, S., \& Snowber, C. (2009, May). Fierce, tender, mischievous: An arts-based inquiry/performance of teacher vulnerabilities in the classroom. Paper presented at the CSSE Annual Conference. Carleton University, Ottawa.

Wiebe, S. (2013). Aesthetic/Empathetic punctures through poetry: A Lacanian slip into something other than education. In B. White \& T. Constantino [Eds.], Aesthetics, Empathy, and Education, (pp. 135-151). New York: Peter Lang.

Wiebe, S. (2014). The lid, the Leggo, and the super Leggo. English Practice, 56(1), 1920.

Wiebe, S. (2015). The strong poets as unconscious mentor metaphors. In N. Ng-A-Fook, A. Ibrahim, \& G. Reis (Eds.), Provoking curriculum studies: Strong poetry and the arts of the possible in education. New York, NY: Routledge.

\section{Author Biography}

Dr. Sean Wiebe is poet and an Associate Professor at the University of Prince Edward Island. For the last three he has been researching the connections among critical thinking and writing and arts-based methodologies. A portfolio of his work can be accessed at http://upei.academia.edu/SeanWiebe. 